\title{
Software Requirements Specification for RELAP-7
}

Hongbin Zhang, David Andrs, Richard Martineau, Nancy Kyle, Hollis Henry, Stella McKirdy

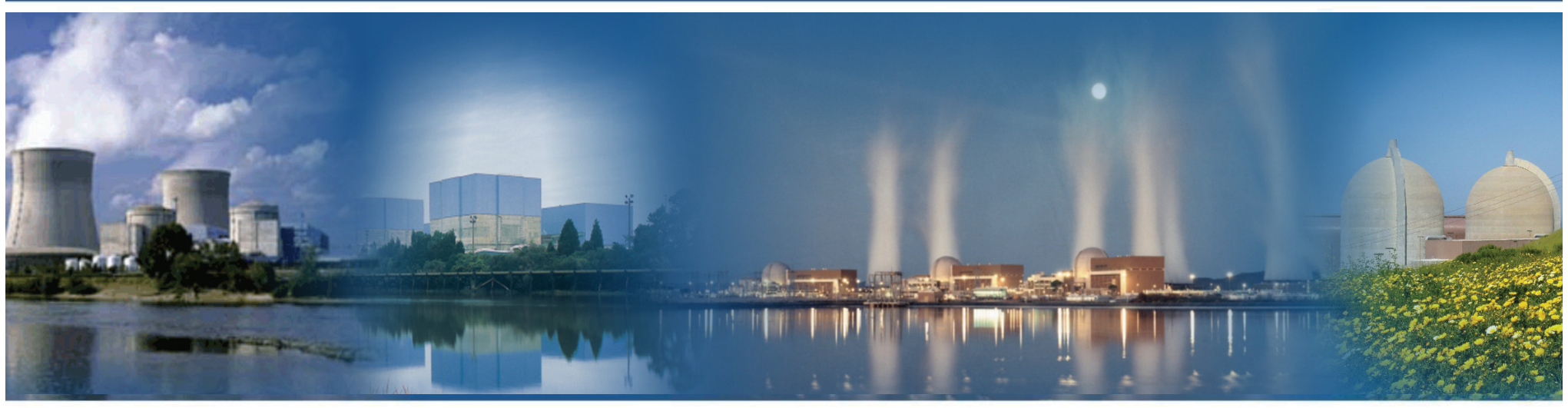

April 2017

U.S. Department of Energy Office of Nuclear Energy 


\section{DISCLAIMER}

This information was prepared as an account of work sponsored by an agency of the U.S. Government. Neither the U.S. Government nor any agency thereof, nor any of their employees, makes any warranty, expressed or implied, or assumes any legal liability or responsibility for the accuracy, completeness, or usefulness, of any information, apparatus, product, or process disclosed, or represents that its use would not infringe privately owned rights. References herein to any specific commercial product, process, or service by trade name, trade mark, manufacturer, or otherwise, does not necessarily constitute or imply its endorsement, recommendation, or favoring by the U.S. Government or any agency thereof. The views and opinions of authors expressed herein do not necessarily state or reflect those of the U.S. Government or any agency thereof. 


\section{CONTENTS}

INTRODUCTION

$\begin{array}{ll}\text { Purpose of this Plan } & 6\end{array}$

$\begin{array}{ll}\text { System Scope } & 6\end{array}$

$\begin{array}{ll}\text { Constraints } & 6\end{array}$

Policies and Regulations $\quad 6$

Environmental, Health, Safety, and Security Considerations $\quad 7$

System Criticality

Control of Information $\quad 7$

$\begin{array}{ll}\text { Assumptions and Dependencies } & 7\end{array}$

$\begin{array}{lr}\text { Applicable Standards } & 8\end{array}$

$\begin{array}{lr}\text { Apportioning of Requirements } & 8\end{array}$

$\begin{array}{lr}\text { STAKEHOLDERS NEEDS } & 8\end{array}$

$\begin{array}{lr}\text { Stakeholders } & 8\end{array}$

$\begin{array}{ll}\text { Stakeholder Needs } & 8\end{array}$

$\begin{array}{lr}\text { SYSTEM OVERVIEW } & 8\end{array}$

$\begin{array}{ll}\text { System Description } & 8\end{array}$

$\begin{array}{lr}\text { Components } & 9\end{array}$

Pipe 9

Boundaries 9

Pipe with Heat Structure $\quad 9$

$\begin{array}{ll}\text { Core Channel } & 10\end{array}$

$\begin{array}{ll}\text { Junction/Branch } & 10\end{array}$

$\begin{array}{ll}\text { Pump } & 10\end{array}$

$\begin{array}{ll}\text { Jet Pump } & 10\end{array}$

$\begin{array}{ll}\text { Turbine } & 10\end{array}$

$\begin{array}{ll}\text { Separator/Dryer } & 10\end{array}$

Downcomer $\quad 10$

Valves 11

Wet Well 11

Subchannel 11

Point Kinetics $\quad 11$

Accumulator 12

$\begin{array}{ll}\text { Pressurizer } & 12\end{array}$ 
$\begin{array}{ll}\text { Problem Scenarios } & 12\end{array}$

Natural Circulation $\quad 12$

Water Hammer 12

Large Break LOCAs 13

Small Break LOCAs $\quad 13$

Increase in Heat Removal Events $\quad 13$

Decrease in Heat Removal Events $\quad 14$

Reactivity and power distribution anomaly events $\quad 14$

Boiling water reactor instability events $\quad 14$

Anticipated transient without scram events 15

Station Blackout $\quad 15$

PWR Thermal Shock 16

Users Interaction 16

Developers $\quad 16$

Analysts 16

Interface with Users 16

$\begin{array}{ll}\text { SYSTEM REQUIREMENTS } & 17\end{array}$

$\begin{array}{ll}\text { Technical/Functional Requirements } & 17\end{array}$

General Functional Requirements 17

Pipe Functional Requirements 17

Pipe with Heat Structure Functional Requirements 18

Inlet Functional Requirements $\quad 18$

Oulet Functional Requirements 19

Closed End Functional Requirements

Free Boundary Functional Requirements $\quad 19$

Heat Structure Functional Requirements $\quad 20$

Core Channel Functional Requirements 20

Reactor Power Functional Requirements 20

Junction Functional Requirements $\quad 20$

Pump Functional Requirements $\quad 21$

Jet Pump Functional Requirements $\quad 21$

Turbine Functional Requirements 21

Separator/Dryer Functional Requirements $\quad 21$

DownComer Functional Requirements $\quad 22$

Valves Functional Requirements 22

Wet Well Functional Requirements 22

Accumulator Functional Requirements 22

Pressurizer Functional Requirements $\quad 22$

Subchannel Functional Requirements 22 
Models 23

Natural Circulation Scenarios $\quad 23$

Water Hammer Scenarios $\quad 23$

LBLOCA Scenarios 23

SBLOCA Scenarios $\quad 24$

Increase in Heat Removal Events Scenarios $\quad 24$

Decrease in Heat Removal Events Scenarios $\quad 24$

Reactivity and Power Distribution anomaly events Scenarios 24

$\begin{array}{ll}\text { Boiling water reactor instability events } & 24\end{array}$

Anticipated transient without scram events $\quad 24$

Station Blackout $\quad 24$

PWR Thermal Shock $\quad 25$

Multi-physics Multi-App Coupling $\quad 25$

Design Inputs, Outputs and Design Constraints 25

Input File Structure $\quad 25$

Design Constraints $\quad 25$

Output File Structure $\quad 25$

Extensibility $\quad 26$

System Interfaces $\quad 26$

Installation Considerations $\quad 26$

REVIEW AND CONTROL OF THE SOFTWARE REQUIREMENTS 27

$\begin{array}{lr}\text { DOCUMENT MAINTENANCE } & 27\end{array}$

$\begin{array}{lr}\text { REFERENCES } & 27\end{array}$

$\begin{array}{lr}\text { DEFINITIONS AND ACRONYMS } & 28\end{array}$

$\begin{array}{lr}\text { Definitions } & 28\end{array}$

$\begin{array}{ll}\text { Acronyms } & 28\end{array}$ 


\section{INTRODUCTION}

\subsection{Purpose of this Plan}

The purpose of this document is to specify the software requirements necessary to achieve the function and capabilities presented in the RELAP-7 Theory Manual. This specification is intended for use by those performing nuclear power plant (NPP) reactor systems safety analysis.

\subsection{System Scope}

The RELAP-7 (Reactor Excursion and Leak Analysis Program) will be the next generation nuclear reactor system safety analysis code developed at Idaho National Laboratory (INL). The code will be based on the INL's modern scientific software development framework MOOSE (Multi-Physics Object Oriented Simulation Environment). The overall design goal of RELAP-7 is to take advantage of the previous thirty years of advancements in computer architecture, software design, numerical integration methods, and physical models.

RELAP-7 will become the main reactor systems simulation toolkit for LWRS (Light Water Reactor Sustainability) programs RISMC (Risk Informed Safety Margin Characterization) effort and the next generation tool in the RELAP reactor systems analysis application series. The key to the success of RELAP-7 is the simultaneous advancement of physical models, numerical methods, and software design while maintaining a solid user perspective. Physical models include both PDEs (Partial Differential Equations) and ODEs (Ordinary Differential Equations) and experimental based closure models. RELAP-7 will utilize well-posed governing equations for two-phase flow, which can be strictly verified in a modern verification and validation effort. RELAP-7 will use modern numerical methods, which allow implicit time integration, second-order schemes in both time and space, and strongly coupled multiphysics.

\subsection{Constraints}

\subsubsection{Policies and Regulations}

The system shall adhere to strict software quality requirements meeting For ASME NQA-1-2008 with the NQA1a2009 addenda standards.

The system shall comply with the requirements of LWP-13620, Managing Information Technology Assets. 


\subsubsection{Environmental, Health, Safety, and Security Considerations}

There are no environmental, health, safety, nor security considerations that specifically apply to the installation and use of RELAP-7.

\subsubsection{System Criticality}

The system quality level has been determined to be QL-1 as documented in Quality Level Determination No. ALL-000833 and Safety Software Determination No. SSD-000635.

\subsubsection{Control of Information}

For many of the potential users, there will be a need to insert proprietary data (e.g. fuel material properties) and correlations (e.g. CHF correlations) into the code, otherwise the code will have limited utility to these users.

\subsection{Assumptions and Dependencies}

The core dependency for RELAP-7 to function is the MOOSE framework. MOOSE provides a general platform for solving the physics problems of interest for the simulation of NPP systems behavior. MOOSE provides capabilities for solving a general set of coupled partial differential equations using the finite element method. This includes support for equation solvers, file input/output, infrastructure for communication between processors in a parallel high performance computing environment, finite element data structures and functions, and a modular architecture that permits incorporation of physics models within an application derived from MOOSE.

The physical models provided by RELAP-7 are implemented as classes that are derived from MOOSE classes that provide pluggable interfaces for basic functionality needed by any physics code based on MOOSE. These include constructs such as Kernels, Boundary Conditions, etc.

RELAP-7 adds physics models to the base capabilities provided by MOOSE to provide a powerful, flexible tool for modeling NPP systems behavior during normal operation and a variety of accident conditions.

Minimum system requirements are:

- A POSIX compliant UNIX including the two most recent versions of OS X and most current versions of Linux.

- RAM: 4GB for optimized compilation (8GB for debug compilation), 2GB per core execution

- Disk: $100 \mathrm{~GB}$

- Compilers: gcc, clang, or Intel

- Python 2.6+

- Git 


\subsection{Applicable Standards}

- PLN-4005, SQAP for MOOSE and MOOSE-Based Applications

- INL/EXT-14-31366 (Revision 2), RELAP-7 Theory Manual

\subsection{Apportioning of Requirements}

In some instances, the models reported in this initial version of the Software Requirements Specification cover phenomena which are not yet implemented, for example, the species balance equation for two phase flows. But when it made sense to include derivations, which we have already developed, or descriptions of models which are currently ongoing, such as the entropy viscosity method, we have included such.

\section{STAKEHOLDERS NEEDS}

\subsection{Stakeholders}

The stakeholders for RELAP-7 include DOE's LWRS Program. Once the code is developed to a state of maturity, other stakeholders will include DOE's Consortium of Advanced Simulation of Light Water Reactors (CASL) Program, DOE's Nuclear Energy Advanced Modeling and Simulation (NEAMS) Program, and the Electric Power Research Institute (EPRI).

\subsection{Stakeholder Needs}

The risk-informed safety margin characterization (RISMC) methodology of the LWRS Program aims at developing and demonstrating a risk-assessment method coupled to safety margin quantification that can be used by decision makers as part of their margin recovery strategies. Toward that end, an advanced RISMC toolkit is being created, which enables more accurate representation of NPP safety margins. The RELAP-7 code is an important component of the advanced RISMC toolkit to perform NPP systems safety analyses.

\section{SYSTEM OVERVIEW}

\subsection{System Description}

The purpose of RELAP-7 is to be the next-generation NPP systems safety analysis code. NPP systems safety analysis codes are constructed to reduce the extreme complexity and physical multi-dimensionality of NPPs into a tractable numerical computational problem. They are designed to simulate licensing basis transients and both postulated and actual NPP accidents. RELAP-7 will be a new thermal-hydraulics code that employs one-dimensional (1-D) flow networks of pipes, combinations of simple zero-dimensional (0-D), 1-D, and two-dimensional (2-D) structures to represent complicated reactor components, and a 0-D point-kinetics representation to model the design features of reactor systems. 
RELAP-7 will incorporate a unique software design, will use advanced numerical methods, and will be flexible in fidelity of physics representation through a sophisticated multiphysics coupling capability. Furthermore, the numerical algorithm to be implemented in RELAP-7 is capable of generating significantly reduced numerical error through the use of high-order spatial and temporal integration. RELAP-7 NPP simulation capabilities will focus on the current fleet of boiling water reactor (BWR) and pressurized water reactor (PWR) NPPs. Additional components including PWR-specific and BWR- specific components and additional closures are anticipated in future years for advanced light water reactor (LWR) concepts, such as small modular reactors (SMRs).

\subsection{Components}

The RELAP-7 code is intended to be an advanced system analysis tool based on components to represent the major physical processes in the reactor system. A real reactor system is very complex and contains hundreds of different physical components. It is impractical to resolve the real geometry of the entire system. Instead simplified thermal hydraulic models are used to represent (via "nodalization") the major physical components and describe the major physical processes (such as fluids flow and heat transfer). There are four main types of components: (1) 1-D components describing the piping network of the reactor system, (2) 2-D heat structures that simulate heat conduction, (3) zero-dimensional (0-D) components for setting boundary conditions, and (4) 0-D components for connecting 1-D components.

\subsubsection{Pipe}

Pipe is the most basic component. It is a 1-D component which simulates thermal fluids flow in a pipe. It can be either single or two phase flow.

\subsubsection{Boundaries}

Pipe or duct inlets and outlets, as well as pipe or duct closed ends or free boundary are treated as zero dimensional (0-D) components for setting boundary conditions.

\subsubsection{Pipe with Heat Structure}

The pipe with heat structure component will simulate fluid flow in a 1-D pipe coupled with 2-D heat conduction through the pipe wall. The adiabatic, Dirichlet, or convective boundary conditions could be prescribed at the outer surface of the pipe wall. The heat structure geometry could be either of a plate or cylindrical type.

\subsubsection{Core Channel}

The core channel component simulates the coolant flow and heat conduction inside a fuel rod as well as the conjugate heat transfer (CHT) between the coolant and the fuel rod. The fuel rod will be modeled as 2-D heat conduction structure 
adjacent to the 1-D fluid flow channel model. Both plate type fuel rod and cylindrical fuel rod type could be simulated. The 2-D heat structure representing solid fuel will be able to deal with typical LWR fuel rod geometry with clad/gap/fuel pellet sub-geometries. The single and two-phase fluid flow models and CHT model will be strongly coupled.

\subsubsection{Branch}

The pipe network branch model will be a 0-D component representing a joint/junction model for arbitrary number of conjoined pipes. The branch component will have loss coefficients that will be provided by industry manufacturers.

\subsubsection{Pump}

The pump is a $0-\mathrm{D}$ junction component where the fluid enters the pump near the axis and the rotor accelerates the fluid to high speed. The fluid then passes through a diffuser which is a progressively enlarging pipe, which permits recovery of the dynamic NPP operating pressure.

\subsubsection{Jet Pump}

Jet pumps are considered as part of the reactor cooling system. The pumps are installed in the annular region between the core barrel and the outside reactor vessel. The driving head for these jet pumps is provided by the pressure head provided by the discharge of the recirculation pumps.

\subsubsection{Turbine}

A turbine is a $0-\mathrm{D}$ component that extracts thermal energy from pressurized steam and uses it to do mechanical work on a rotating output shaft to generate large quantities of electrical power.

\subsubsection{Separator/Dryer}

The separator dryer is a 0-D component that will model both the steam separator and moisture dryer in BWRs and the steam generator system components in PWRs. The separator removes water from the two-phase flow and the dryer further increases the quality of the steam and provides high quality dry steam to the turbine.

\subsubsection{Downcomer}

The downcomer is a reactor component with a large volume that connects the feedwater pipe and the downcomer outlet. The volume is filled with vapor at the top and liquid at the bottom. During transients, the liquid level will increase or decrease (depending on the nature of the transient), which affects the mass flow rate through the reactor core; therefore, it is important to track the liquid level for transient analysis. 


\subsubsection{Valves}

The valve component connects one pipe on each side. The valve is initiated with a given state, i.e. fully open or fully closed. It then starts to react (i.e., close or open) and is triggered either by a preset user given trigger time or by a trigger event. In its opening status, either fully open or partially open, it serves as a regular flow junction with form losses. In its fully closed status, the connected two pipes are physically isolated. The current valve model also includes the gradually open/close capability similar to a motor driven valve to simulate the physical behavior of a valve open/close procedure. It also has the benefit of avoiding spurious numerical oscillations that are caused by an instantaneous open/close procedure.

\subsubsection{Wet Well}

The wet well component is designed to simulate the suppression chamber of a BWR reactor, which is composed of water space and gas space. In the event of station blackout, the suppression pool of the wet well condenses the steam from the reactor and provides the cooling water to the reactor.

\subsubsection{Subchannel}

The subchannel component models the local conditions of fluid flow and heat transfer within fuel assemblies so that the margin to the established thermal limits, such as the departure from nucleate boiling ratio (DNBR) for PWRs, or the minimum critical power ratio for BWRs can be quantified.

\subsubsection{Point Kinetics}

The reactor point kinetics model is the simplest model that can be used to compute the transient behavior of the neutron fission power in a nuclear reactor. The power is computed using the space-independent, or point kinetics, approximation which assumes that power can be separated into space and time functions. The point kinetics model will compute both the immediate (prompt and delayed neutrons) fission power and the power from decay of fission products. The immediate power is that released at the time of fission and includes power from kinetic energy of the fission products and neutron moderation. Decay power is generated as the fission products undergo radioactive decay. The decay power model will be based on the 1979 ANSI/ANS Standard, the 1994 ANSI/ANS Standard, or the 2005 ANSI/ANS Standard.

\subsubsection{Accumulator}

An accumulator is a tank connected a cold leg of a PWR. It contains large amounts of borated water with a pressurized nitrogen gas bubble in the top. If the pressure of the primary system drops below the low pressure set point, the nitrogen will force the borated water out of the tank and into the reactor coolant system. These tanks are designed to provide water to the reactor coolant system 
during emergencies in which the pressure of the primary drops very rapidly, such as large primary breaks. The cold leg accumulators do not require electrical power to operate.

\subsubsection{Pressurizer}

The pressurizer is the component in the reactor coolant system which provides a means of controlling the system pressure. Pressure is controlled by the use of electrical heaters, pressurizer spray, power operated relief valves, and safety valves. If the pressure increases and exceeds the desired setpoint, the spray line will spray cold water into the steam space. The cold water will condense the steam into water, which will reduce pressure. If pressure continues to increase, the pressurizer relief valves will open and dump steam to the pressurizer relief tank. If this does not relieve pressure, the safety valves will lift, also discharging to the pressurizer relief tank. If pressure starts to decrease, the electrical heaters will be turned on to boil more water into steam, and therefore increase pressure.

\subsection{Problem Scenarios}

RELAP-7 is intended to be used for the system thermal-hydraulics simulation for a wide range of phenomena and events including licensing basis transients and accidents. The problem scenarios are briefly described here.

\subsubsection{Natural Circulation}

Natural circulation refers to the ability of a fluid in a system to circulate continuously due to gravitational effects upon differences of fluid density. The difference of density is the only driving force in natural circulation. A fluid system designed for natural circulation will have a heat source and a heat sink. Each of these is in contact with some of the fluid in the system, but not all of it. The heat source is positioned lower than the heat sink.

\subsubsection{Water Hammer}

Water hammer is a pressure wave caused when a fluid in motion is forced to stop or change direction suddenly. A water hammer commonly occurs when a valve closes suddenly at an end of a pipeline system, and a pressure wave propagates in the pipe. It is also called hydraulic shock. This pressure wave can cause major problems, ranging from noise and vibration to pipe collapse.

\subsubsection{Large Break Loss of Coolant Accidents}

Large break loss of coolant accident (LBLOCA) is defined as the loss of reactor coolant caused by a double-ended break of the largest coolant pipe. There are four phases involved in an LBLOCA: (1) blowdown, (2) refill, (3) reflood and (4) long term cooling. The blowdown period (0-30 s) occurs as a result of a break in the coolant system through which the primary coolant is rapidly expelled. Within a fraction of a second after the break, the core voids and goes through departure from nucleate boiling. The negative void reactivity rapidly shuts down the core. 
The refill period occurs between 30 and $40 \mathrm{~s}$ following the start of the LOCA. The primary pressure has decreased to a level at which the low-pressure injection system activates and begins to inject water into the system. The lower plenum begins to fill with accumulator water as coolant bypass diminishes. The reflood period occurs between 40 and $200 \mathrm{~s}$; it begins at the time when the lower plenum has filled and the core begins to refill.

\subsubsection{Small Break Loss of Coolant Accidents}

The small break loss of coolant accident (SBLOCA) is defined for piping breaks up to sizes where the reactor remains pressurized despite the occurrence of the break. This encompasses up to 3 inches diameter holes in the primary circuit piping. In the SBLOCA, the reactor depressurizes more slowly than in the LBLOCA, following a different set of physical phenomena. Since the core remains at high pressure for a long time in a SBLOCA, it is not possible to activate the Low Pressure Safety Injection (LPSI) system, with its relatively large rate of coolant flow, until a late stage into the accident.

\subsubsection{Increase in Heat Removal Events}

For PWRs the increase in heat removal events includes:

- Increase in feedwater flow

- Decrease in feedwater temperature

- Inadvertent opening of a secondary relief or safety valve

- Steam line break

For BWRs the increase in heat removal events include:

- Loss of a feedwater heater

- Steam pressure regulator malfunction or failure that results in an increase in steam flow

The safety concern for the increase in heat removal events is that the resulting moderator overcooling will cause a positive reactivity insertion and challenge the specified acceptable fuel design limits. Therefore the phenomena and processes of interest are related to the excessive heat transfer and the reactivity addition phenomena and processes.

\subsubsection{Decrease in Heat Removal Events}

The decrease in heat removal events includes:

- Turbine trip

- Loss of load

- MSIV closure

- Steam pressure regulator failure (BWR)

- Loss of main feedwater

- Loss of condenser vacuum 
- Loss of non-emergency AC power

- Feedwater line break (PWR)

The safety concerns for the decrease in heat removal events are that the reactor will overheat and challenge the specified acceptable fuel design limits, and that the RCS pressure will challenge the design overpressure limit. Therefore the phenomena and processes of interest are related to the mismatch between the heat source and heat sink, and the pressurization and pressure relief processes and phenomena.

\subsubsection{Reactivity and Power Distribution Anomaly Events}

The reactivity and power distribution anomalies events includes:

- Control rod bank withdrawal at zero power event

- Control rod bank withdrawal at power event

- Single control rod withdrawal at power event

- Control rod assembly drop accident at cold and zero power (BWR)

- Control rod drop at power (PWR)

- Rod ejection accident (PWR)

- Moderator dilution events (PWR)

- Reactor coolant pump startup event (PWR)

- Flow controller malfunction causing an increase in core flow rate (BWR)

The safety concerns for the reactivity and power distribution anomalies events are that the reactor will overheat and challenge the specified acceptable fuel design limits, and that the RCS pressure will challenge the design overpressure limit. Therefore the phenomena and processes of interest are related to the mismatch between the reactor power distribution and the core cooling capability, and the mismatch between the heat source that causes RCS pressurization and the pressure relief processes and phenomena.

\subsubsection{Boiling Water Reactor Instability Events}

BWR instabilities occur when an operating condition becomes unstable after some perturbations in system parameters. As a consequence, state variables identifying the reactor working conditions are observed to oscillate in different ways depending on the modalities of the departure from the stable operating point. Power oscillations can, for large amplitudes, have an adverse influence on the fuel integrity. From the point of view of the BWR safety, the most important type of power instability is the reactivity oscillations excited by thermal-hydraulic mechanisms.

Two types of instability by reactivity have been characterized:

1) In-phase (core-wide) instability. In this case, all the variables (power, mass flow, pressure, etc.) oscillate in phase determining a 
limit cycle; from the point of view of safety, this type of instability has relatively small relevance, unless it is associated with an ATWS.

2) Out-of-phase instability. In this case, the instabilities occur when a neutronic azimuthal mode is excited by thermal-hydraulic mechanisms causing asymmetric power oscillations, while part of the reactor operates at high-mass flow and low-power level, in the other part the opposite happens; this behaviour warrants detailed studies because of safety implications.

\subsubsection{Anticipated Transient without Scram Events}

The anticipated transients without scram (ATWS) include all anticipated operational occurrences (AOOs) with an assumed failure of the reactor protection system to trip the reactor. All PWRs have an ATWS mitigation circuit (AMSAC) to assist in event mitigation by tripping the main turbine and actuating the auxiliary feedwater system. The Babcock \& Wilcox and Combustion Engineering PWRs also have a diverse scram system that successfully trips the reactor and the transient response is essentially the same. The other PWRs rely on the AMSAC actuation and reactivity feedback and operator action to mitigate the ATWS event, including injection of boric acid. The BWR strategy for mitigating ATWS events combines the alternate rod injection system, the standby liquid control system to inject boric acid and negative reactivity, and an automatic recirculation pump trip. The BWR ATWS response for some events may involve large power oscillations. The safety concern for the ATWS event is to maintain core cooling during the mismatch between reactor power and the heat sink, and for RCS pressure to stay below the RCS pressure limit that is applicable for the ATWS event.

\subsubsection{Station Blackout}

The station blackout (SBO) scenario causes a prolonged loss of all AC power. The reactor immediately trips and then only steam-driven cooling water sources or possibly special safety systems designed for SBO-like events are actuated. For PWRs the event is typically mitigated by the turbine-driven auxiliary feedwater pump (or an alternative pump that does not rely on normal or emergency site $\mathrm{AC}$ power). Loss of cooling to the reactor coolant pump seals is assumed (unless an alternative seal cooling system is available) and a SBLOCA results from seal failure. So, the event can start as a decrease in secondary heat removal event with natural circulation conditions, followed by a SBLOCA leading to core uncovery. For BWRs the event is mitigated by the turbine-driven ECCS pumps, which are of different designs. A loss of DC battery power can lead to a loss of control to these pumps and a gradual reduction in vessel inventory due to boiloff leading to core uncovery. The safety concern for the SBO event is to maintain core cooling until a source of electrical power to the safeguards systems can be restored. 


\subsubsection{PWR Thermal Shock}

PWR overcooling events have a risk of causing a thermal shock to the reactor vessel welds. Overcooling can result from loss of secondary pressure control (steam line breaks and valve failures), steam generator overfeeds, and following actuation of the high pressure injection system due to the direct injection of cold water into the cold legs. These events are partially mitigated by the engineered safeguards that close the MSIVs and isolated main feedwater. Operator action is required to throttle or terminate high pressure injection system to prevent excessive overcooling and to control pressure. The phenomena of interest are associated with the sources of the overcooling and the pressurization and pressure relief processes.

\subsection{Users Interaction}

\subsubsection{Developers}

A developer is a scientist or engineer that develops additional physics modules to expand or improve the capabilities of RELAP-7.

This user will typically have a background in modeling and simulation techniques and/or numerical analysis but may only have a limited skill-set when it comes to object-oriented coding and the $\mathrm{C}++$ language. They will be responsible for following and enforcing the appropriate software development standards. They will be responsible for designing, implementing and maintaining the software.

\subsubsection{Analysts}

These are users that will run RELAP-7 on an end application to perform nuclear reactor system safety analysis. They will also perform various post processing steps on the simulations they perform. These users may interact with developers of the system requesting new features and reporting bugs found and will typically make heavy use of the input file format.

\subsubsection{Interface with Users}

The system shall interact with users in two ways: via command line and via graphical user interface.

The system shall use the command line as defined by MOOSE.

The system shall employ a GUI for building a model of a power plant and specifying elements of a virtual control room. 


\section{SYSTEM REQUIREMENTS}

The system is dependent on MOOSE for performance requirements and only specifies technical/functional requirements that are performed by the system.

\subsection{Technical/Functional Requirements}

\subsubsection{General Functional Requirements}

\begin{tabular}{|l|l|}
\hline F1.1 & The system shall allow specifying global gravity vector \\
\hline F1.2 & $\begin{array}{l}\text { The system shall check the integrity of the input file prior to the } \\
\text { execution }\end{array}$ \\
\hline
\end{tabular}

\subsubsection{Pipe Functional Requirements}

\begin{tabular}{|l|l|}
\hline F2.1 & The system shall provide a straight pipe with single phase flow \\
\hline F2.2 & The system shall provide a straight pipe with two phase flow \\
\hline F2.3 & The system shall allow specifying a position of the pipe \\
\hline F2.4 & The system shall allow specifying a length of the pipe \\
\hline F2.5 & The system shall allow specifying initial condition on the pipe \\
\hline F2.6 & $\begin{array}{l}\text { The system shall allow specifying cross-sectional area, heat flux } \\
\text { perimeter and hydraulic diameter }\end{array}$ \\
\hline F2.7 & $\begin{array}{l}\text { The system shall allow specifying heat flux coming to/from the } \\
\text { pipe }\end{array}$ \\
\hline F2.8 & The system shall allow specifying wall temperature \\
\hline F2.9 & The system shall allow prescribing a friction coefficient \\
\hline F2.10 & The system shall allow prescribing a heat convective coefficient \\
\hline F2.11 & $\begin{array}{l}\text { The system shall allow prescribing a interfacial drag coefficient for } \\
\text { two-phase flow }\end{array}$ \\
\hline F2.12 & $\begin{array}{l}\text { The system shall allow choosing the fluid properties used in the } \\
\text { pipe }\end{array}$ \\
\hline F2.13 & $\begin{array}{l}\text { The system shall allow specifying heat transfer geometry } \\
\text { coefficient }\end{array}$ \\
\hline F2.14 & The system shall allow for a bend pipe \\
\hline F2.16 & \begin{tabular}{l} 
The system shall allow for controlling the wall temperature \\
\hline
\end{tabular} \\
\hline
\end{tabular}




\subsubsection{Pipe with Heat Structure Functional Requirements}

\begin{tabular}{|l|l|}
\hline F3.1 & $\begin{array}{l}\text { The system shall allow for a pipe with a heat structure attached to } \\
\text { it }\end{array}$ \\
\hline F3.2 & $\begin{array}{l}\text { The system shall allow specifying adiabatic boundary condition in } \\
\text { the heat structure }\end{array}$ \\
\hline F3.3 & $\begin{array}{l}\text { The system shall allow for specifying convective boundary } \\
\text { condition in the heat structure }\end{array}$ \\
\hline F3.4 & $\begin{array}{l}\text { The system shall allow for specifying temperature boundary } \\
\text { condition in the heat structure }\end{array}$ \\
\hline F3.5 & $\begin{array}{l}\text { The system shall allow for specifying additional heat source in the } \\
\text { flow channel }\end{array}$ \\
\hline F3.6 & $\begin{array}{l}\text { The system shall allow for specifying initial temperature in the } \\
\text { heat structure }\end{array}$ \\
\hline F3.7 & $\begin{array}{l}\text { The system shall allow for specifying materials in the heat } \\
\text { structure }\end{array}$ \\
\hline
\end{tabular}

\subsubsection{Inlet Functional Requirements}

\begin{tabular}{|l|l|}
\hline F4.1 & $\begin{array}{l}\text { The system shall allow prescribing mass flow rate and temperature } \\
\text { for single phase flow }\end{array}$ \\
\hline F4.2 & $\begin{array}{l}\text { The system shall allow prescribing mass flow rate and temperature } \\
\text { for two phase flow. }\end{array}$ \\
\hline F4.3 & $\begin{array}{l}\text { The system shall allow prescribing density and velocity for single } \\
\text { phase flow }\end{array}$ \\
\hline F4.4 & $\begin{array}{l}\text { The system shall allow prescribing density and velocity for two } \\
\text { phase flow }\end{array}$ \\
\hline F4.5 & $\begin{array}{l}\text { The system shall allow prescribing stagnation enthalpy and } \\
\text { momentum for single phase flow }\end{array}$ \\
\hline F4.6 & $\begin{array}{l}\text { The system shall allow prescribing stagnation enthalpy and } \\
\text { momentum for two phase flow }\end{array}$ \\
\hline F4.7 & $\begin{array}{l}\text { The system shall allow prescribing stagnation pressure and } \\
\text { temperature for single phase flow }\end{array}$ \\
\hline F4.8 & $\begin{array}{l}\text { The system shall allow prescribing stagnation pressure and } \\
\text { temperature for two phase flow }\end{array}$ \\
\hline F4.9 & \begin{tabular}{l} 
The system shall allow reversible inlet conditions \\
\hline
\end{tabular}
\end{tabular}




\begin{tabular}{|l|l|}
\hline F4.10 & $\begin{array}{l}\text { The system shall allow for controlling the mass flow rate and } \\
\text { temperature for single phase flow. }\end{array}$ \\
\hline F4.11 & $\begin{array}{l}\text { The system shall allow for controlling the mass flow rate and } \\
\text { temperature for two phase flow. }\end{array}$ \\
\hline F4.12 & $\begin{array}{l}\text { The system shall allow for controlling the density and velocity for } \\
\text { single phase flow. }\end{array}$ \\
\hline F4.13 & $\begin{array}{l}\text { The system shall allow for controlling the density and velocity for } \\
\text { two phase flow. }\end{array}$ \\
\hline F4.14 & $\begin{array}{l}\text { The system shall allow for controlling the stagnation pressure and } \\
\text { temperature for single phase flow. }\end{array}$ \\
\hline F4.15 & $\begin{array}{l}\text { The system shall allow for controlling the stagnation pressure and } \\
\text { temperature for two phase flow. }\end{array}$ \\
\hline
\end{tabular}

\subsubsection{Outlet Functional Requirements}

\begin{tabular}{|l|l|}
\hline F5.1 & $\begin{array}{l}\text { The system shall allow prescribing an outlet pressure for single } \\
\text { phase flow }\end{array}$ \\
\hline F5.2 & $\begin{array}{l}\text { The system shall allow prescribing an outlet pressure for two phase } \\
\text { flow. }\end{array}$ \\
\hline F5.3 & The system shall allow reversible outlet conditions \\
\hline F5.4 & $\begin{array}{l}\text { The system shall allow for controlling the outlet pressure for single } \\
\text { phase flow. }\end{array}$ \\
\hline F5.5 & $\begin{array}{l}\text { The system shall allow for controlling the outlet pressure for two } \\
\text { phase flow. }\end{array}$ \\
\hline
\end{tabular}

\subsubsection{Closed End Functional Requirements}

\begin{tabular}{|l|l|}
\hline F6.1 & $\begin{array}{l}\text { The system shall allow prescribing a solid wall boundary condition } \\
\text { for single phase flow }\end{array}$ \\
\hline F6.2 & $\begin{array}{l}\text { The system shall allow prescribing a solid wall boundary condition } \\
\text { for two phase flow }\end{array}$ \\
\hline
\end{tabular}

\subsubsection{Free Boundary Functional Requirements}

\begin{tabular}{|l|l|}
\hline F7.1 & $\begin{array}{l}\text { The system shall allow prescribing a free inflow/outflow boundary } \\
\text { condition for single phase flow }\end{array}$ \\
\hline
\end{tabular}


\begin{tabular}{|l|l}
\hline F7.2 & The system shall allow prescribing a free inflow/outflow boundary
\end{tabular} condition for two phase flow

\subsubsection{Heat Structure Functional Requirements}

\begin{tabular}{|l|l|}
\hline F8.1 & The system shall provide a 2-D heat structure \\
\hline F8.2 & $\begin{array}{l}\text { The system shall allow specifying geometry of the heat structure } \\
\text { and its blocks }\end{array}$ \\
\hline F8.3 & The system shall allow axisymmetric heat structure \\
\hline F8.4 & The system shall allow Cartesian heat structure \\
\hline F8.5 & The system shall allow multiple blocks within one heat structure \\
\hline F8.6 & $\begin{array}{l}\text { The system shall allow defining material properties in the heat } \\
\text { structure blocks }\end{array}$ \\
\hline F8.7 & $\begin{array}{l}\text { The system shall allow defining initial temperature of the heat } \\
\text { structure }\end{array}$ \\
\hline F8.8 & $\begin{array}{l}\text { The system shall allow specifying power profile in the heat } \\
\text { structure }\end{array}$ \\
\hline F8.9 & $\begin{array}{l}\text { The system shall allow specifying power fraction of the reactor } \\
\text { power }\end{array}$ \\
\hline F8.10 & $\begin{array}{l}\text { The system shall allow specifying power density in the heat } \\
\text { structure }\end{array}$ \\
\hline
\end{tabular}

\subsubsection{Core Channel Functional Requirements}

\begin{tabular}{|l|l|}
\hline F9.1 & The system shall provide core channel with single phase model \\
\hline F9.2 & The system shall provide core channel with two phase model \\
\hline
\end{tabular}

\subsubsection{Reactor Power Functional Requirements}

\begin{tabular}{|l|l|}
\hline F10.1 & $\begin{array}{l}\text { The system shall provide for fully coupled native point kinetics } \\
\text { model with thermal-hydraulic reactivity feedback for simulating } \\
\text { strong reactor transients. }\end{array}$ \\
\hline F10.2 & $\begin{array}{l}\text { The system shall support specifying reactor power in order to } \\
\text { simulate normal transient reactor operation, such as startup, } \\
\text { shutdown, and load following. }\end{array}$ \\
\hline
\end{tabular}




\subsubsection{Junction Functional Requirements}

\begin{tabular}{|l|l|}
\hline F11.1 & $\begin{array}{l}\text { The system shall allow for connecting } 2 \text { single-phase pipes } \\
\text { together }\end{array}$ \\
\hline F11.2 & The system shall allow for connecting 2 two-phase pipes together \\
\hline F11.3 & $\begin{array}{l}\text { The system shall allow for connecting one pipe perpendicular to } \\
\text { another pipes (T-shape) (single phase flow model) }\end{array}$ \\
\hline F11.4 & $\begin{array}{l}\text { The system shall allow for connecting one pipe perpendicular to } \\
\text { another pipes (T-shape) (two phase flow model) }\end{array}$ \\
\hline F11.5 & $\begin{array}{l}\text { The system shall allow for connecting multiple pipes on one end to } \\
\text { multiple pipes on the other end (all pipes with single phase flow } \\
\text { model). }\end{array}$ \\
\hline F11.6 & $\begin{array}{l}\text { The system shall allow for connecting multiple pipes on one end to } \\
\text { multiple pipes on the other end (all pipes with two phase flow } \\
\text { model). }\end{array}$ \\
\hline
\end{tabular}

\subsubsection{Pump Functional Requirements}

\begin{tabular}{|l|l|}
\hline F12.1 & The system shall provide a pump model for single phase flow. \\
\hline F12.2 & The system shall provide a pump model for two phase flow \\
\hline F12.3 & $\begin{array}{l}\text { The system shall allow for driving the pump with a turbine } \\
\text { component }\end{array}$ \\
\hline F12.4 & The system shall allow for controlling the pump head. \\
\hline
\end{tabular}

\subsubsection{Jet Pump Functional Requirements}

\begin{tabular}{|l|l}
\hline F13.1 & The system shall provide a jet pump model for BWR analysis.
\end{tabular}

\subsubsection{Turbine Functional Requirements}

\begin{tabular}{|l|l|}
\hline F14.1 & $\begin{array}{l}\text { The system shall provide power turbine model for single phase } \\
\text { flow }\end{array}$ \\
\hline F14.2 & The system shall provide power turbine model for two phase flow \\
\hline F14.3 & The system shall provide Terry turbine model for single phase flow \\
\hline F14.4 & The system shall provide Terry turbine model for two phase flow \\
\hline
\end{tabular}




\subsubsection{Separator/Dryer Functional Requirements}

\begin{tabular}{|l|l}
\hline F15.1 & $\begin{array}{l}\text { The system shall provide a model to remove water from the } \\
\text { two-phase flow and provide high quality steam to the power } \\
\text { turbine }\end{array}$
\end{tabular}

\subsubsection{DownComer Functional Requirements}

\begin{tabular}{|l|l} 
F16.1 & The system shall provide representative water level in the BWR
\end{tabular} downcomer

\subsubsection{Valves Functional Requirements}

\begin{tabular}{|l|l|}
\hline F17.1 & $\begin{array}{l}\text { The system shall provide the control and functions of a valve for } \\
\text { single phase flow }\end{array}$ \\
\hline F17.2 & $\begin{array}{l}\text { The system shall provide the control and functions of a check valve } \\
\text { for single phase flow }\end{array}$ \\
\hline F17.3 & $\begin{array}{l}\text { The system shall provide the control and functions of a valve for } \\
\text { two phase flow }\end{array}$ \\
\hline F17.4 & $\begin{array}{l}\text { The system shall provide the control and functions of a check valve } \\
\text { for two phase flow }\end{array}$ \\
\hline
\end{tabular}

\subsubsection{Wet Well Functional Requirements}

\begin{tabular}{|l|l|}
\hline F18.1 & $\begin{array}{l}\text { The system shall provide a model for representative pressure, water } \\
\text { level, water and gas mixture temperatures in the wet well of a } \\
\text { BWR }\end{array}$
\end{tabular}

\subsubsection{Accumulator Functional Requirements}

\begin{tabular}{|l|l|}
\hline F19.1 & The system shall provide a model for representative water level in
\end{tabular} the accumulator during transient conditions

\subsubsection{Pressurizer Functional Requirements}

\begin{tabular}{|l|l|}
\hline F20.1 & $\begin{array}{l}\text { The system shall provide a model for representative pressure and } \\
\text { water level. }\end{array}$ \\
\hline F20.2 & The system shall provide control functions for the electric heater. \\
\hline F20.3 & $\begin{array}{l}\text { The system shall provide control functions for the pressurizer } \\
\text { spray. }\end{array}$ \\
\hline F20.4 & $\begin{array}{l}\text { The system shall provide control functions for the power operated } \\
\text { relief valves. }\end{array}$ \\
\hline
\end{tabular}


\begin{tabular}{|l|l} 
F20.5 & The system shall provide control functions for the safety valves.
\end{tabular}

\subsubsection{Subchannel Functional Requirements}

\begin{tabular}{|l|l|}
\hline F21.1 & The system shall provide a subchannel model for single phase flow \\
\hline F21.2 & The system shall provide a subchannel model for two phase flow. \\
\hline
\end{tabular}

\subsubsection{Models}

\begin{tabular}{|c|c|}
\hline F22.1 & The system shall incorporate heat conduction model. \\
\hline F22.2 & The system shall incorporate single phase flow model. \\
\hline F22.3 & $\begin{array}{l}\text { The system shall incorporate a well-posed seven-equation, } \\
\text { two-pressure model for two-phase flow water and steam situations. }\end{array}$ \\
\hline F22.4 & The system shall incorporate a non-condensable gas model. \\
\hline $\mathrm{F} 22.5$ & $\begin{array}{l}\text { The system shall incorporate the IAPWS- } 95 \text { water-steam equation } \\
\text { of state. }\end{array}$ \\
\hline F22.6 & The system shall incorporate the nitrogen equation of state. \\
\hline F22.7 & The system shall incorporate the Boron transport model \\
\hline F22.8 & $\begin{array}{l}\text { The system shall incorporate the closure correlations specified in } \\
\text { the Theory Manual }\end{array}$ \\
\hline F22.9 & $\begin{array}{l}\text { The system shall come with AECL-IPPE } 1995 \text { critical heat flux } \\
\text { lookup table }\end{array}$ \\
\hline F22.10 & $\begin{array}{l}\text { The system shall allow for conjugate heat transfer between a pipe } \\
\text { and a heat structure }\end{array}$ \\
\hline F22.11 & $\begin{array}{l}\text { The system shall allow for variable body force vector (acceleration } \\
\text { and gravity) }\end{array}$ \\
\hline
\end{tabular}

\subsubsection{Natural Circulation Scenarios}

\begin{tabular}{|l|l|}
\hline F23.1 & The system shall solve a single phase natural circulation problem \\
\hline F23.2 & The system shall solve a two phase natural circulation problem \\
\hline
\end{tabular}

\subsubsection{Water Hammer Scenarios}

\begin{tabular}{|l|l|}
\hline F24.1 & The system shall solve a single phase water hammer problem. \\
\hline F24.2 & The system shall solve a two phase water hammer problem. \\
\hline
\end{tabular}




\subsubsection{LBLOCA Scenarios}

\begin{tabular}{|l|l} 
F25.1 & The system shall simulate the LOFT Experiment L2-5, which
\end{tabular} simulated a double-ended cold leg break.

\subsubsection{SBLOCA Scenarios}

\begin{tabular}{|l|l}
\hline F26.1 & The system shall simulate Loss-of-Fluid Test (LOFT) Experiment
\end{tabular} L3-7, which simulated a 1-inch cold leg break.

\subsubsection{Increase in Heat Removal Events Scenarios}

\begin{tabular}{|l|l|}
\hline F27.1 & $\begin{array}{l}\text { The system shall solve the PWR main steam line break benchmark } \\
\text { problem specified in NEA/NSC/DOC(99)8. }\end{array}$
\end{tabular}

\subsubsection{Decrease in Heat Removal Events Scenarios}

\begin{tabular}{|l|l}
\hline F28.1 & The system shall simulate LOFT Turbine Trip Experiment
\end{tabular}
L6-7/L9-2 (NUREG/CR-3257).

\subsubsection{Reactivity and Power Distribution Anomaly Events Scenarios}

\begin{tabular}{|l|l}
\hline F29.1 & The system shall simulate LOFT Rapid Control Rod Withdrawal
\end{tabular} Experiment L6-8B2 (NUREG/CR-2930).

\subsubsection{Boiling Water Reactor Instability Events}

\begin{tabular}{|l|l}
\hline F30.1 & $\begin{array}{l}\text { The system shall simulate the Ringhals } 1 \text { Stability Benchmark } \\
\text { problem specified in NEA/NSC/DOC(96)22. }\end{array}$
\end{tabular}

\subsubsection{Anticipated Transient Without Scram Events}

\begin{tabular}{|l|l|}
\hline F31.1 & $\begin{array}{l}\text { The system shall simulate LOFT Anticipated Transient Without } \\
\text { Scram Experiment L9-3 (NUREG/CR-2717) }\end{array}$ \\
\hline
\end{tabular}




\subsubsection{Station Blackout}

\begin{tabular}{|l|l|}
\hline F32.1 & $\begin{array}{l}\text { The system shall simulate the station blackout scenarios for a PWR } \\
\text { such as Analyses of Natural Circulation During a Surry Station } \\
\text { Blackout (NUREG/CR-5214, EGG-2547). }\end{array}$ \\
\hline F32.2 & $\begin{array}{l}\text { The system shall simulate the station blackout scenarios for a } \\
\text { BWR. }\end{array}$ \\
\hline
\end{tabular}

\subsubsection{PWR Thermal Shock}

\begin{tabular}{|l|l}
\hline F33.1 & $\begin{array}{l}\text { The system shall perform Thermal-Hydraulic Analyses of } \\
\text { Pressurized Thermal Shock Sequences for the Oconee-1 } \\
\text { Pressurized Water Reactor (NUREG/CR-3761, EGG-2310). }\end{array}$
\end{tabular}

\subsubsection{Multiphysics MultiApp Coupling}

\begin{tabular}{|l|l|}
\hline F34.1 & $\begin{array}{l}\text { The system shall allow for using wall temperature from an external } \\
\text { MOOSE-based application. }\end{array}$ \\
\hline F34.2 & $\begin{array}{l}\text { The system shall allow for using power distribution from an } \\
\text { external MOOSE-based application. }\end{array}$ \\
\hline F34.3 & $\begin{array}{l}\text { The system shall allow for modifying the cross-sectional area of } \\
\text { the flow channel. }\end{array}$ \\
\hline
\end{tabular}

\subsection{Design Inputs, Outputs and Design Constraints}

\subsubsection{Input File Structure}

\begin{tabular}{|l|l|}
\hline DI1.1 & The system shall use the input file syntax as defined by MOOSE. \\
\hline DI1.2 & The system shall employ the reactor component based input file. \\
\hline
\end{tabular}

\subsubsection{Design Constraints}

\begin{tabular}{|l|l|}
\hline DC1.1 & $\begin{array}{l}\text { The system shall be implemented in MOOSE, INL's HPC } \\
\text { development and runtime framework. }\end{array}$ \\
\hline DC1.2 & $\begin{array}{l}\text { The system shall be written with object oriented programming } \\
\text { language } \mathrm{C}++.\end{array}$ \\
\hline
\end{tabular}


\begin{tabular}{|l|l}
\hline DC1.3 & The system uses SI units.
\end{tabular}

\subsubsection{Output File Structure}

\begin{tabular}{|l|l|}
\hline DO1.1 & The system shall use the output capabilities of MOOSE framework. \\
\hline
\end{tabular}

\subsubsection{Extensibility}

\begin{tabular}{|l|l|}
\hline E1.1 & $\begin{array}{l}\text { The system shall provide a way to supply proprietary data for fuel } \\
\text { material properties. }\end{array}$ \\
\hline E1.2 & $\begin{array}{l}\text { The system shall provide a way to supply proprietary closure } \\
\text { correlations. }\end{array}$ \\
\hline E1.3 & The system shall allow the use of arbitrary fluid properties. \\
\hline
\end{tabular}

\subsection{System Interfaces}

\begin{tabular}{|l|l|}
\hline SI1.1 & MOOSE \\
\hline SI1.2 & $\begin{array}{l}\text { libSBTL: Spline based table lookup library for water and steam } \\
\text { properties as defined by IAPWS95 standard. }\end{array}$ \\
\hline
\end{tabular}

\subsection{Installation Considerations}

Detailed installation instructions, including the following installation considerations, will be included in the RELAP-7 User's Manual.

\begin{tabular}{|l|l|}
\hline IC1.1 & The user shall obtain a valid license \\
\hline IC1.2 & $\begin{array}{l}\text { MOOSE Environment Setup: The user's system environment must } \\
\text { be set up for MOOSE. }\end{array}$ \\
\hline IC1.3 & $\begin{array}{l}\text { SSH Key Setup: The user's SSH key must be set up to allow the } \\
\text { user to establish a secure connection between their computer and } \\
\text { GitLab. }\end{array}$ \\
\hline IC1.4 & $\begin{array}{l}\text { Code Checkout: It is necessary to build LibMesh before building } \\
\text { any application. Once LibMesh has been successfully compiled, } \\
\text { the system can be compiled. }\end{array}$ \\
\hline
\end{tabular}




\begin{tabular}{|l|l|}
\hline IC1.5 & $\begin{array}{l}\text { Verification Testing: Once the system has been compiled } \\
\text { successfully, it is recommended to run the tests to make sure the } \\
\text { version of the code installed is running correctly. }\end{array}$ \\
\hline
\end{tabular}

\section{REVIEW AND CONTROL OF THE SOFTWARE REQUIREMENTS}

The system software requirements shall be controlled and verified as specified in PLN-4005. Once approved, the system requirements establish the functional baseline for the software.

\section{DOCUMENT MAINTENANCE}

The technical lead is responsible for maintaining this SRS. This SRS is controlled per LWP1201, "Document Management." Revisions to this SRS will occur on an as needed basis as a result of reviews, audits, and requested changes. Modifications to this SRS must be reviewed and approved by the same organizational roles as the original release.

\section{REFERENCES}

The following are references for this SRS. All Idaho National Laboratory (INL) policies and procedures referenced are the current version at the time this SRS was approved.

- ASME NQA-1-2008 with the NQA1a2009 addenda, "Quality Assurance Requirements for Nuclear Facility Applications," American Society of Mechanical Engineers, First Edition, August 31, 2009.

- ISO/IEC/IEEE 24765:2010(E), "Systems and software engineering Vocabulary," First Edition, December 15, 2010.

- LWP1201, “Document Management."

- LWP-13620, Managing Information Technology Assets, Revision 17, 7/28/2014.

- PLN-4005, SQAP for MOOSE and MOOSE-Based Applications, Revision 3, $3 / 26 / 2016$.

- MOOSE-SRS Revision 0, Draft

- INL/EXT-14-31366, RELAP-7 Theory Manual, Revision 2, March 2016

- RELAP5 Assessment: - LOFT Turbine Trip L6-7 /L9-2, NUREG/CR-3257, July 1983.

- Experiment data report for LOFT anticipated transient-without-scram Experiment L9-3, NUREG/CR-2717; EGG-2195. 
- Analyses of natural circulation during a Surry station blackout using SCDAP/RELAP5, NUREG/CR-5214; EGG-2547.

- RELAP5 Thermal-Hydraulic Analyses of Pressurized Thermal Shock Sequences for the Oconee-1 Pressurized Water Reactor, NUREG/CR-3761, EGG-2310.

- Experiment data report for LOFT anticipated transient experiment series L6-8, NUREG/CR-2930.

- Ringhals 1 Stability Benchmark, NEA/NSC/DOC(96)22.

- PRESSURISED WATER REACTOR MAIN STEAM LINE BREAK (MSLB) BENCHMARK, NEA/NSC/DOC(99)8.

\section{DEFINITIONS AND ACRONYMS}

This section defines, or provides the definition of, all terms and acronyms required to properly understand this SRS.

\subsection{Definitions}

Component: A component in the system is a simplified representation of the functions of the physical component in a NPP.

\subsection{Acronyms}

0-D Zero Dimensional

1-D One Dimensional

2-D Two Dimensional

AC Alternate Current

AECL Atomic Energy Canada Limited

AMSAC ATWS mitigation circuit

ANS American Nuclear Society

ANSI American National Standards Institute

AOO Anticipated Operational Occurrences

ASME American Society of Mechanical Engineers

ATWS Anticipated Transient Without Scram 
BWR Boiling Water Reactor

CASL Consortium for Advanced Simulation of Light Water Reactors

CHF Critical Heat Flux

CHT Conjugate Heat Transfer

DNB Departure from Nucleate Boiling

DNBR Departure from Nucleate Boiling Ratio

DOE Department of Energy

ECCS Emergency Core Cooling System

EPRI Electric Power Research Institute

GUI Graphical User Interface

HPC High Performance Computing

IAPWS The International Association for the Properties of Water and Steam

INL Idaho National Laboratory

IPPE Institute of Physics and Power Engineering

IT Information Technology

LBLOCA Large Break Loss of Coolant Accidents

LOFT Loss Of Fluid Test Facility

LPSI Low Pressure Safety Injection

LWR Light Water Reactor

MIT Massachusetts Institute of Technology

MOOSE Multiphysics Object Oriented Simulation Environment

MSIV Main Steamline Isolation Valve

NEAMS Nuclear Energy Advanced Modeling and Simulation

NPP Nuclear Power Plant

NQA Nuclear Quality Assurance

ODE Ordinary Differential Equation 
OOP Object Oriented Programming

PDE Partial Differential Equation

PWR Pressurized Water Reactor

QA Quality Assurance

RCS Reactor Coolant System

RELAP Reactor Excursion and Leak Analysis Program

RISMC Risk Informed Safety Margin Characterization

SBLOCA Small Break Loss of Coolant Accidents

SBO Station Blackout

SI The International System of Metric Units

SMR Small Modular Reactor

SRS Software Requirements Specification 